\title{
Threads of Jewish Identity in Salon Culture: Rahel Varnhagen
}

\author{
and Florine Stettheimer
}

RACHEL FROHLICH

\begin{abstract}
The Major Research Paper is submitted Master of Arts
\end{abstract} in partial fulfillment of the requirements for the degree of

Joint Graduate Program in Communication \& Culture Ryerson University - York University

Toronto, Ontario, Canada

September 16, 2009 


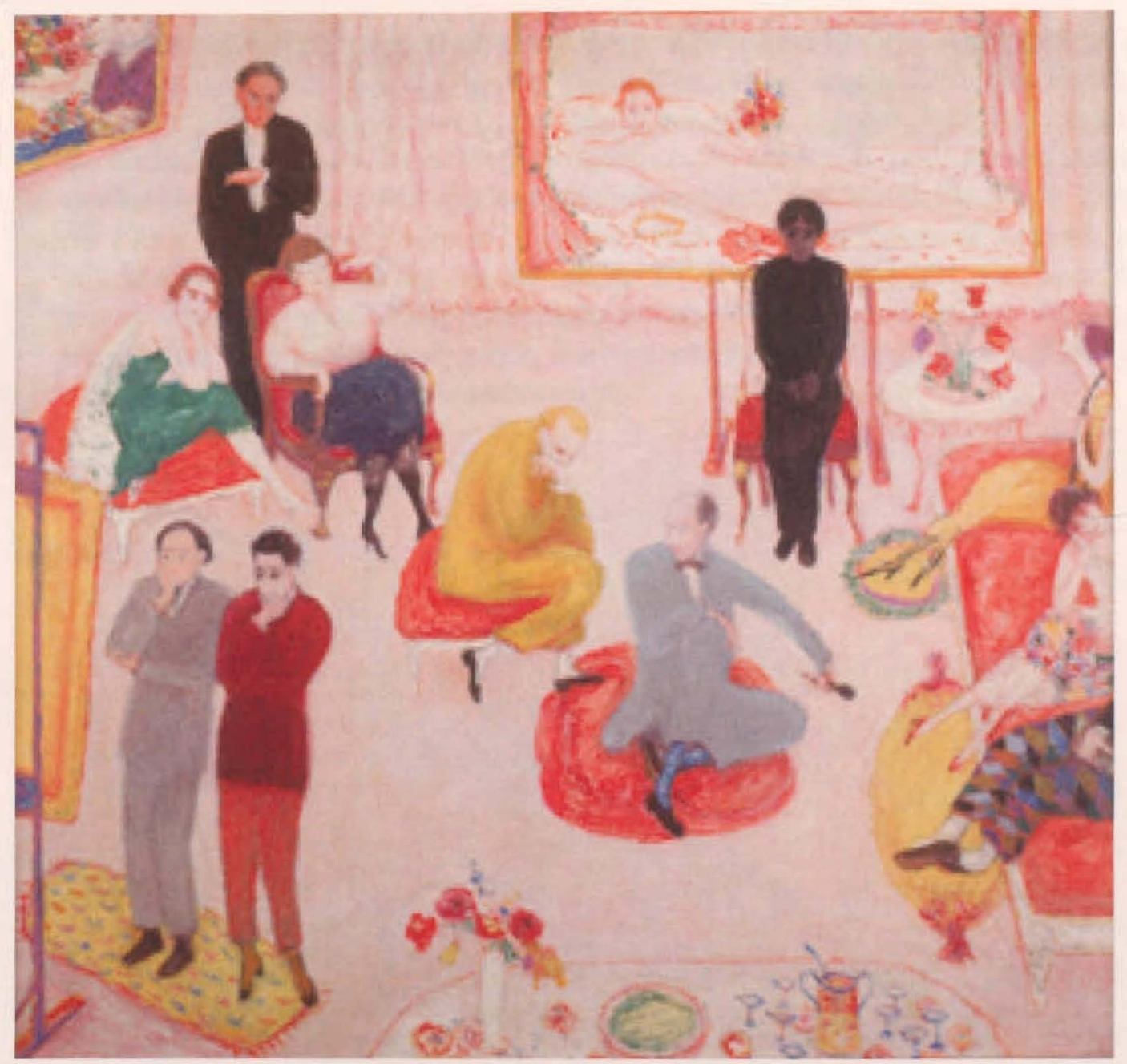

Florine Stettheimer, Soirée (1917-19), 28 x 30 in. Yale Collection of American Literature, Beinecke Rare Book and Manuscript Library, Yale University, New Haven. 


\section{Acknowledgements}

I wish to express my appreciation and deepest gratitude to those who inspired and supported my research and progress throughout the writing process. For her expert guidance and support in developing this major research paper, I am indebted to my supervisor, Dr. Irene Gammel, whose enthusiastic approach to modernist literary circles along with the 2008 graduate student exhibit, The Moveable Feast: Experience the Modernist Salon at Ryerson University first sparked my interest in this topic. I would also like to thank my second reader, Dr. Ruth Panofsky, for her expert and timely feedback, which further strengthened my argument throughout. I would also like to thank my mother and father, Barbara and Allan Frohlich, for their love and vital support of my academic endeavours.

\section{Rachel Frohlich}




\section{Table of Contents}

Introduction: What is a Salon?

1. Rahel Varnhagen's Salon: A Space of Assimilation $\quad 10$

2. Florine Stettheimer's Salon: Social Harmony 25

3. The Salon as an Alternative Space 41

$\begin{array}{ll}\text { Works Cited } & 43\end{array}$

$\begin{array}{ll}\text { Appendix } & 48\end{array}$ 


\section{Introduction: What is a Salon?}

Sociability. Actually that which is most human among human beings! the essence and point of departure of all that is moral! Without companions, without comrades during this earthly existence, we would ourselves not be persons, and any ethical action, law, or thought, [would be] impossible.

- Rahel Varnhagen (quoted in Tewarson 43)

Florine Stettheimer's painting Soirée (1917-19), which serves as the frontispiece to this essay, depicts what may be considered a self-portrait of sorts: a scene representing a social gathering at the Stettheimer salon on the Upper West Side. As depicted in the painting, habitués of differing social, political and artistic backgrounds have come together to socialize with other artists, enjoy the food displayed in the foreground, and view the new work painted by their hostess; in fact, Florine herself is represented in the nude in a large canvas in the centre of the painting with the guests delicately turning their backs to the painting. This ironic painting of a live salon scene at the Stettheimers allows viewers a glimpse into a social, cultural, and artistic institution that has remained somewhat under researched in the ways in which it defies some of the rules of mainstream society. Sociability, evoked in the epigraph, was also the focus of Rahel Varnhagen's early nineteenth-century salon in Berlin, a space in which racial and gender boundaries were crossed. Located in the private domestic space of somebody's home, the 
salon was an influential social institution and a vehicle that ultimately empowered women as this essay will document by exploring Rahel Varnhagen and Florine Stettheimer's important careers as salonières. As this essay will argue, the salon especially empowered doubly marginalized Jewish women and allowed them to overcome limitations of the traditional roles considered appropriate for Jewish women who were able to claim strong intellectual, social, and artistic identities by using the salon as their vehicle.

In their exhibition catalogue Jewish Women and Their Salons, Emily Bilski and Emily Braun note that the study of the salon tends to overlook the salonière in her influence, social intelligence, and her role in fostering social progress. This essay hopes to address this gap but before we turn to Varnhagen and Florine as successful salonières, in Berlin and New York respectively, what exactly is a salon? Focussing in particular on the central role of the Jewish salonière in shaping European and North American salon culture for three centuries, Bilski and Braun provide a helpful taxonomy: they describe the salon as a gathering of individuals, occurring on the same day at the same time each week usually accompanied by the serving of food and by cultural activities such as the reading of letters and viewing of art, which in turn often stimulated art making. Invitations for the salon were initially sent by a personal messenger or by word of mouth, and eventually sent through the postal service and by telephone in later years. The successful salon consisted of habitués, a group of regular salon attendees comprised of talented and well-known individuals from the artistic and literary world or influential individuals in public service roles, as well as close friends who regularly attended the 
salon. Occasional new visitors and out-of-town guests also provided contrast and energy to the successful salon.

Historically, salons appeared in the seventeenth-century, where a rising wealthy bourgeoisie class began to eclipse the aristocratic nobility for whom status was conferred by birth, not acquired by wealth. The salon as an institution aided in this transition by providing, as Steven Kale writes: "a space for social fusion and cultural homogenization among the diverse elements of an aristocracy." He continues: "The genius of salons, and of salonières lay in their ability to maintain a delicate balance between exclusivity and openness, between inclusions and exclusions, so that the aristocracy could have both a means of producing social cohesion and a vehicle for the dissemination of traits meant to characterize a wider society of elites undergoing redefinition" (143). Moreover, the early French seventeenth-century salon provided a private space for the usually segregated sexes to mix in an intimate and yet platonic environment.

In eighteenth-century France, with the bourgeoisie encroaching on the nobility's role as social leaders, salons provided the nobility with a means to control their sense of place by allowing them to have cultural authority and enabling them to access social prestige. By the mid-eighteenth-century, the salon was more than a place to mingle with the opposite sex but became an institutional foundation for the Enlightenment by reason of the increasing ability of salonières to sway public opinion through their management of conversation within the salon walls (Bilski and Braun 6; Kale 116). Often described as the master of ceremonies, the salonière was the authoritative conductor of the salon, tending to be exceptionally charismatic and a figure who "provided her guests the model of a rational, exhilarating, discursive style" (Bilski and Braun 2-3). The salonière's job 
was to create a gathering that drew in different personalities, talents, and personal backgrounds, balancing various temperaments while ensuring some spontaneity within the conversation which took place. The salon environment was characterized by refinement, intelligence, conversation, and civility and gave the salonières the perfect opportunity to control behaviour and to establish French civility. Part of its appeal was that it provided newly rising French bourgeoisie a chance to acquire formerly exclusively aristocratic skills like dress, speech, manners and an introduction to literature and the arts; thus, the salonières aided in integrating the newcomers into the social elite.

In fact, with the rise of the modern state in the eighteenth-century, noble women experienced a loss in role and position, which was crucial for the rise of the salon, as Joan Landes writes in Women and the Public Sphere in the Age of the French Revolution: "public-private oppositions were being reinforced in ways that foreclosed women's earlier independence in the street, in the marketplace, and, for elite women, in the public spaces of the court and aristocratic household." Concurrently, however, the salon still granted women a certain degree of social power and became an alternative to the court society whereby women as salonières became "purveyors of culture" (22). Intelligent and cultured salonières provided a forum for men to socialize, but even more significantly, they provided an unprecedented forum for women to exchange ideas amongst intellectual equals. Thus "the discursive space of the salon could not ignore its female constituency," as Bilski and Braun observe (6), and the eighteenth-century salon space was actually defined by its feminine characteristics such as refinement, tolerance, and agreeableness.

In her article "Enlightenment Salons: The Convergence of Female and Philosophic Ambitions" Dena Goodman counters the general assumption that women 
formed salons out of a desire for fame and power through associations with powerful men. Goodman argues that this general explanation "assumes the centrality of men in understanding the actions of women. It is what the men who frequented the salons thought and what historians of the salon have continued to write" (332). This belief, along with its misogynistic underpinnings, is derived from the anecdotes of these same brilliant men and is consequently found within books about the salon such as Eloges de Madame Geoffrin, contemporaine de Madame du Deffand by André Morellet who writes that Mme. Geoffrin formed a salon in order to acquire a celebrity status. Yet, salonières of the Enlightenment period "must be viewed as intelligent, self-educated, and educating women who reshaped the social forms of their day to their own social, intellectual, and educational needs" (332). Goodman makes the thoughtful distinction that unlike men in their careers, salonières were not awarded with an income for their work. The salon acted as a "career based on a long apprenticeship and careful study, resulting in the independence of a mastership" (333).

Furthermore, Goodman demonstrates that the practice of letter writing is what pushed the salon of the Enlightenment outside the private realm and into the public world. The salon and letters formed an information network which helped to distribute new ideas. Goodman refers in particular to the letters written by the French philosophes which were copied, recited out loud and often published bridging the distance between the writer and the reader. Letter writing can simulate oral communication not unlike the conversation found in the salon as Margaretmary Daley explains, as the eighteenthcentury salonières put the same amount of effort into their letters as they put into their conversations. Moreover, letters helped to maintain and develop salon membership: 
"incoming mail was quarried for news, gossip, information, ideas; letters were also shared, read aloud, passed around, and generally inserted in the discourse of the salon," as Dena Goodman observes (340-341). The letter was a correspondence from one person to another as well as a literary form of artistic expression. As a precursor to the modern salon, not only did letters come in and out of the salon but moreover, poetry, newsletters, and manuscripts also frequently appeared within the salon. Musical and other theatrical performances were also hosted in salons which positioned the salon as "laboratory for the new," as Bilski and Braun explain (7). As well, the beginnings of art criticism grew out of the salon as music and art received critiques from an educated and diverse public.

According to Bilski and Braun, the salons took on an even more overt and distinctly social and progressive role in the nineteenth-century, in the age of mass society, by providing a venue for hosting political parties, for organizing dissenters, and for offering a breeding ground for the avant-garde movement. Moreover, the salon also offered an alternative to the strict behaviour enforced in the public domain. During this period women of the salon were viewed as intermediaries as they helped to develop and encourage art, music and literature in one of the only venues which gave women reasonable access to intellectual and artistic pursuits. As women were excluded from academies of higher learning and not entitled to hold office or enrol in the military, the salon allowed women to further their careers through critique from peers and by meeting famed and renowned personalities.

Nonetheless, as Bilski and Braun argue: "[t]he salon has never been studied comprehensively as a vehicle of female emancipation and assimilation for a Jew, an institution of modern secular culture that spread throughout Europe after 1789 and lasted 
until World War II" (3). Bilski and Braun document that Jewish salonières actually constituted an inexplicably large percentage of noteworthy salonières. The birth of Enlightenment ideas such as tolerance and universality allowed the Jewish salonières to emerge in eighteenth-century Europe which gave these women an opportunity to experience the extent to which both Jews and women could be emancipated. Like their counterparts, the non-Jewish salonières, the Jewish salonières came from wealthy families but desired to emancipate themselves from the restrictions of strict Orthodox Jewish society. Facing persecution, oppression, and segregation, many Jews longed to be accepted into all aspects of mainstream society. These Jewish salonières straddled the opportunity of having social power while facing the boundaries enforced through racial prejudice as the "ultimate outsiders on the inside" (Bilski and Braun 15). Likewise, as Bilski and Braun contend, hosting a salon provided "the ticket to the mainstream: personal association with the upper class and intelligentsia was the swiftest means of arriving, of mastering Western European high culture" (16). The late nineteenth-century Jewish salonières became further integrated into the mainstream aided by the Jewish Reform movement which sought to depart from traditional Orthodox Jewish practices in order to further Jewish acculturation into mainstream Christian society (Herzog 63). This integrated position allowed many to find success as artists and writers and propel the avant-garde and modernism movements. However, even Jewish salonières who only claimed their Jewish heritage culturally or through family tradition could not escape being positioned as the 'other' facing prejudice still embedded in society.

In this essay, then, I propose to juxtapose Rahel Varnhagen (1771-1833), a BerlinJew, with Florine Stettheimer (1871-1944), a New York Jew of German descent, to 
illustrate that to mitigate their status as outsiders, both salonières sought emancipation as Jewish women and integration into their respective mainstream societies through the establishment of their salons. The multi-layered role of the salonière to some extent aided the two women in overcoming the double marginalization of being a woman and a Jew. As we shall see, Varnhagen and Florine benefited socially and culturally from opening their homes to guests, as it provided the opportunity to engage in intellectual debates, educate themselves on various topics and participate in public life. They used the salon's structure effectively to further their social lives, as well as their personal literary and artistic goals. Similarly, both women rejected or transcended the constraints of marriage and challenged the traditional feminine role of wife and mother. Varnhagen, for example, married late, while Florine, one hundred years later forwent marriage altogether to devote her time and energy to painting.

Noteworthy because of their similarities, as much as because of their disparities, each of these salonières represented a significant model of what remarkable Jewish women could achieve through the salon: Rahel Varnhagen from the period when Jewish salons were just evolving; her successor, Florine Stettheimer, from the brink of the modern period - each from different ends of the historical progression of establishing salon culture. Each salonière signified what emancipated, enlightened Jewish women were capable of achieving as their semi-public salons evolved and into them were woven the larger fabric of society. Sometimes rejecting tradition, sometimes harmonizing it with the avant-garde the salons of these two women always governed their salons with the underpinnings of their personal concepts of an idealized community. For Rahel Varnhagen, as I shall argue, the salon was her social reality - held within the confines of 
her home it was a space where Varnhagen was able voice her humanistic and tolerant sensibilities and affect social change by accepting men and women as equals. But ironically, she found it necessary to disassociate herself from her Jewish background in order to achieve equality in nineteenth-century Germany. Although less open to dissolving class barriers than Varnhagen's, the salon of Florine Stettheimer and her two sisters Ettie and Carrie, was the vehicle that facilitated the Stettheimer sisters' assimilation into society and helped them to overcome gender and racial barriers still maintained in New York society in the early twentieth-century. Ultimately, as I argue, it was the role of salonière that permitted Stettheimer to express her potential as a Jewish woman artist and to attract other marginalized groups for social gatherings and important career partnerships in the Stettheimers' influential salon. 


\section{Rahel Varnhagen's Salon: A Space of Assimilation}

Rahel Varnhagen, née Rahel Levin, was born on May 19, 1771, into a German Jewish family. Varnhagen's father, Levin Markus, was a businessman of considerable wealth, which permitted him and his wife Chaie, as well as his entire family, to enjoy a comfortable life not afforded Berlin Jews of the lower classes. Aside from the great family wealth, Varnhagen's family was ordinary and undistinguished and there was little indication that young Rahel had any particular artistic talent or physical beauty. In fact, Rahel felt that "in addition to lacking beauty, I have no inner grace," and concluded: "it's been decided that I am disgusting I am plainer than ugly" (quoted in Pickett 41). Despite lacking traditionally feminine gifts as well as being an outsider as a Jewish woman in Berlin, Varnhagen grew to great fame with an unequalled intellect and charismatic nature that was quite the opposite of the ideals of femininity promoted at that time, as Varnhagen's biographer Heidi Tewarson observes: "Her work as salonière and epistolary writer lay outside the canonical tradition" (2).

Perhaps this non-traditional focus is the reason that Varnhagen's writings endured and are still read and studied although they may not have been given the full academic inquiry that they deserved (as suggested, for example, by scholars such as Ellen Key, Margaretmary Daley, and Tewarson). In fact, there was renewed interest when the Varnhagen Archive, thought to have been lost after the Second World War, was found in the Jagiellonian Library in Cracow, Poland in the late 1970s. Consisting of a large body of source material on literary Romanticism and nineteenth-century history, the archive features a large portion of Varnhagen's writings along with work from her correspondents. Tewarson maintains that the papers contain information on Varnhagen's 
circle of professional women friends coming from various classes and religious backgrounds. This discovery has led to a six-volume project critically looking at Varnhagen's unpublished work, the majority of which has been written in German (involving scholars such as Barbara Hahn, Ursula Isselstein, Marianne Schuller, Consolona Vigliero, and Renata Buzzo-Márgari). New academic work on Varnhagen indicates that she is a writer who merits scholarly attention, but so does her prominence as a salonière.

Much suggests that Varnhagen's vocation as a salonière has its roots in her own home growing up in Berlin. As a strong-willed young woman, Rahel found herself in conflict with her judgemental and tyrannical father, vehemently opposing the matches to the Jewish men arranged by her family, and it was here that she first sought to separate herself from her Jewish community by opposing the path of traditional marriage and motherhood. As Bertha Meyer writes, it was in her private sanctuary, as she escaped to her attic-room to avoid confrontation that Rahel grew more introspective by focusing on her own philosophical and intellectual questions, while she also became friends with Dorothea and Henrietta Mendelsohn, the daughters of the famous philosopher Moses Mendelsohn. Additionally, Rahel practiced her French and German which proved to be advantageous in the conversations she would soon orchestrate as a salonière. Rahel was also able to find family affection and companionship with her younger brother, Ludwig, a writer who moved within the Berlin literary circles and introduced his writer friends to his sister.

Yet Rahel did not come into her own until her father died in 1790, and the Levin family business was transferred over to Varnhagen's married brother Marcus who 
supported the family. Nineteen-year-old Rahel began to invite guests for tea to discuss cultural issues and music and quickly expanded these vibrant gatherings beyond the level of mere social events, as Meyer writes: "Gradually her attic-room became a favourite meeting-place; statesmen, littérateurs, artists, leading actresses and actors all found here a common ground of lively interest in current politics and culture" (57). These gatherings in the family home on Jägerstraße formed Rahel's first salon where various friends and acquaintances with similar ideals of egalitarian relationships met. It was an opportune time to form a literary circle, for as Deborah Hertz argues in How Jews Became Germans: The History of Conversion and Assimilation in Berlin, this period in Germany was one of great richness for intellectual and artistic life and the value of relationships was explored through romantic literature, whereby the salon also provided an ideal showcase for Varnhagen's skill for bringing out the best in people and for encouraging open communication amongst diverse individuals.

Varnhagen's first salon was pleasant and stimulating although the setting was simple, according to her guests, such as the otherwise little-known Count von Salm and Gustav von Brinckmann. Varnhagen always remained at the centre of the gatherings and von Salm described her vivacious personality as generous, intellectual and stimulating. Like so many salonières (think, for example, of Gertrude Stein or Nathalie Barney), Varnhagen was especially gifted in the art of conversation and was also able to facilitate the flow of conversation from guest to guest and topic to topic so that all enjoyed both speaking and listening to the lively exchange (although, in contrast, as we shall see, Florine Stettheimer spoke through her artwork and left the conversation to her intellectually brilliant sister, Ettie.) 
As Varnhagen reached her twenties she had two objectives in her life, according to Tewarson: "one, to overcome some of the constraints imposed on her as a woman and two, to promote social integration for herself as an assimilated Jew as well as for other marginalized groups" (34). Disinterested in musical performances and public readings, she preferred that thought-provoking conversation be the basis of her salon. To help establish this serious tone Varnhagen intentionally served her guests tea only. Her typical gatherings started in the mid-to-late afternoon and ended on a high note at nine o'clock while guests were still invigorated. The gatherings were modest and regularly consisted of friends, family and guests; however, at times her salon provided an opportunity to interact with "the most eminent men Berlin could show in the literary, scientific, and artistic world," as biographer Ellen Key writes (223). Consequently, the interactions within the semi-private world of Varnhagen's salon demonstrated her ability not only to hold her own, but to command a powerful intellectual presence among her intellectual peers.

The salon Varnhagen presided over encouraged free and open sociability. Interestingly, the term 'salon' was not used at this time in Berlin but rather the institution was referred to as an 'open house' or 'society.' Varnhagen herself referred to her gatherings as "society" (Gesellschaft) or as "our circle" (unser Kreiss). In fact, as Martine Leibovici argues, for Varnhagen, the notion of the salon was something of "a wishful image of a common life shared by Jews and Germans" (917). In actuality there existed a large inequality between Jewish bourgeoisie and the German upper class. Sociability in the eighteenth-century was a very important goal, as many German-Jewish citizens sought equality through their social relationships which could provide social change 
within strict German class barriers. Varnhagen challenged this disparity by treating her habitués as equals, thereby challenging social conventions and class distinctions of late eighteenth-century Berlin. Varnhagen's salon was part of this progressive movement of sociability to bridge class distinctions, as Kay Goodman writes: "There they formulated a liberal ideology alien to aristocratic courtly life in a social institution, the salon, which blatantly fostered inter-racial and inter-class friendships" (135).

It is significant to note in this context that Varnhagen was not the first woman to run a salon in Berlin. Other wealthy Jewish women in Berlin hosted salons at the same time including her friend Dorothea Veit (Moses Mendelssohn's daughter), as well as Henriette Lemos Herz, yet it was Varnhagen's salon that gained renown due to her reputation for "superb intellect and tactful social skills" (Daley 48). Many well-known German guests frequented her salon such as the diplomat and philosopher Wilhelm von Humboldt as well as many writers which included Ludwig Tieck, Adalbert von Chamisso, and Friedrich Schlegel; Swedish ambassador Karl Gustav von Brinckmann also attended and subsequently corresponded with Varnhagen through letters over a number of years; as well, Antoni Radziwill and Louis Ferdinand, two Prussian princes, and Friedrich von Gentz, a political analyst, attended regularly (Daley 48). Meanwhile, Varnhagen's Jewish friends also were habitués, including Dorothea and Henriette Mendelssohn, Sara and Marianne Meyer along with David Veit. Thus, her gatherings were egalitarian in breaking social boundaries by including guests of both genders as well as Christians and Jews of all social classes which is precisely what made it socially progressive and interesting to many intellectuals and artists. 
The salon, as I suggest, is an especially appropriate forum for intelligent Jewish women like Varnhagen, as salons of many Jewish women had significant underpinnings in Jewish religious education, a profoundly intellectual tradition based on countering each other's interpretations. The Talmudic tradition validated intellectualism as holy books were not just memorized but also reinterpreted and debated by subsequent generations of male scholars. Young boys had a long-established tradition of being exposed to passages and laws of the Jewish oral and written traditions by a teacher; as young men, they deepened and expanded the knowledge in the tradition of taking opposing sides in scholarly debates with study partners. This intellectualism was not readily accessible to females. In eighteenth-century Berlin wealthy families such as the Varnhagens could afford to hire tutors to educate their daughters in various secular subjects.

Although women were not permitted to participate in the longstanding tradition of Talmudic discourse educated Jewish women inherited an environment of lively verbal exchanges and eventually manifested their own ongoing intellectualism in their homes through the vehicle of the salon with the salonière as a teacher of sorts and the habitués as study partners, as I propose. In fact, this rich intellectual tradition manifested itself for Varnhagen as it did for the Stettheimer sisters and allowed them to engage their guests with intellectual rigor and make the salon a space for intellectual discourse and for asserting power over the salon habitués. In this outgrowth of Talmudic tradition, paradoxically, Varnhagen was granted access to the society to which she aspired: the semi-public realm of the salon where the social discourse reflected Varnhagen's interest not in Jewish religion, but in the more secular humanitarian ideals she espoused. Although she considered herself to be secular, ironically, the invisible threads of Jewish 
tradition were woven into her salon in a manner that was packaged for anti-Semitic society and assimilationist Jews like Varnhagen herself. In this way Varnhagen made subversive use of Jewish culture even as she rejected the Jewish tradition in favour of more assimilationist, enlightened ideals. Her egalitarian ideal which was a challenge to Berlin society at that time can be seen as having its underpinnings in Jewish culture. A strong thread in Jewish culture is to act as a model for society as seen in the book of Isaiah which refers to the Jewish people as "a light to the nations" (The Stone Edition Tanach, Isaiah 42:6). As well, Varnhagen's support of Enlightenment thinker Claude Henri conte de Saint-Simon demonstrated that she ascribed to his utopian view, which she summed up in a letter to Karl Schall: "I believe completely in the progression, the perfectibility, the continued improvement of the universe, toward ever greater understanding and wealth in the highest sense: happiness and the giving of happiness" (quoted in Tewarson 224). She promoted this utopian view in her salon as she sought equality and intellectualism while concurrently subverting this Jewish principle by rejecting its Torah-observant basis and positing herself as an assimilationist. Varnhagen provided this model for change by conceiving her salon as a "light" for personal and social transformation, assimilation and secularism.

Moreover, as Tewarson notes, the Jewish Berlin salonières came from the margins of society "and began in their own small way to transform the lofty concepts of Enlightenment thinking into reality" (41). Varnhagen was aware that the effectiveness of the salon was limited and attendance at salons was not widespread; nevertheless, Varnhagen's salon marked the inception of a more inclusive society for which Varnhagen longed. Even just the appearance of a well-off German visiting a Jewish salon, as Hertz 
(53) writes, was positive for German-Jewish relations. Thus, the Jewish Berlin salonières treated their salons as an environment where they could push the boundaries of society's norms, yet without violating the principles of sociability, as Varnhagen emphasized when she wrote: "whoever ruins sociability, harms it, harms me; whoever damages it, damages me: my innermost self' (quoted in Tewarson 43). Varnhagen showed the links between the social sphere and the personal sphere.

Rahel Varnhagen was part of a marginalized group living in a rigid class society and was among the many social outsiders to speak Yiddish within the home and German in public and thus demonstrated the duality of her status. In Berlin, the Jewish population comprised less than one percent of the total population and reached over 100,000 by 1755 (Dauber 69). Within Berlin, where Jews were a sizeable minority and where educated and assimilated Jews could receive social acceptance individually, Jews as a group still remained cultural and political pariahs. For example, the Haskala, the Jewish enlightenment movement, took place within this learned class which Jeremy Dauber describes as an "elite of parvenu property-owning bourgeois Jewish entrepreneurs" (70). The proponents of the Haskala encouraged values of enlightenment and espoused increasing Jewish integration into European society through secular study. It was this environment that led Varnhagen to renounce her Jewish background. The resulting assimilation into mainstream society increased especially amongst the elite as they tried to mirror their non-Jewish counterparts by bridging a cultural gap between themselves and the rest of Germany's elite.

The Enlightenment with its underpinnings of equal rights held promise for Jews to become equal and emancipated citizens and live assimilated lives within German society. 
The political situation and the propagation of religious tolerance prompted some Jews to believe that they could attain full social and economic integration into German life. Traditional observance of Judaism waned by the $1780 \mathrm{~s}$ along with an increase in baptisms of upper class German Jews. Despite attempts at acceptance and acculturation into German society, anti-Semitism was directed at assimilated Jews in particular. Jews in Berlin were routinely insulted in the streets and stoned. Moreover, all vocational choices made by German Jews had to be approved by German authorities and Jews were barred from holding citizenship (Dauber 75; Tewarson 63).

According to Hannah Arendt's famous biography Rahel Varnhagen: The Life of a Jewish Woman, Varnhagen had a deep desire to escape from her Judaism and enter into the social world of Germany (23-24). For instance, in her correspondence with her close friend David Veit they made reference to their Jewishness through insults or jokes and as a humiliation to be put behind them. In a letter to Veit, Rahel wrote disparagingly: "I shall never accept that I am a Schlemihl and a Jewess" (quoted in Tewarson 57). Refusing to accept her Jewish identity, Varnhagen sought to live as a socially emancipated Jew but felt that her religion prevented her from fitting into mainstream society. As a marginalized eighteenth-century Jew, she looked forward to full assimilation to participate freely in society, even desiring full conversion to Christianity. Varnhagen took steps throughout her life to expunge her Jewish heritage and achieve secular integration and acceptance. Born as Rahel Levin, she changed her last name to Robert and then after her baptism which preceded her 1914 marriage to a non-Jewish German, Karl August Varnhagen von Ense, she followed the custom of changing her first name to Friederike Antonie. In her article "Writing on the Wall: Letters of Rahel 
Varnhagen", Liliane Weissberg suggests that this name change is also reminiscent of Frederick the Great, "who signifies for Rahel the new Germany and Jewish emancipation" (170). Furthermore, this name change signalled her "symbolic step" away from being a "wealthy Jew," bringing her closer to being an aristocratic Gentile. As a salonière Varnhagen was able to live as a "free-lance intellectual." She felt she could live assimilated within a Gentile world, as opposed to within a Jewish circle. This was an arrangement, however, that did not shield her from experiencing anti-Jewish attitudes directed in particular at intellectual women and Jewish salonières (Tewarson 102). As a convert to Christianity, Varnhagen hoped that the salon would further facilitate her assimilation, allowing her to exert social and cultural influence, yet she continued to be confronted with anti-Semitism such as occurred when Varnhagen received certain guests at her salon who nevertheless would not allow her to enter their own homes despite being a convert: she was still perceived as a Jewish salonière. She was subjected, also, to anti-Jewish sentiments from some friends. Wilhelm von Humboldt and his wife Caroline did not approve of Karl August Vamhagen's marriage to a Jewish woman. Moreover, some Christian friends avoided her salon. "They are all gone," she wrote, "My German friends, for how long already; as if they had died, as if they had dispersed!" (quoted in Tewarson 93). Interestingly, despite these overt personal encounters with anti-Semitism, as Tewarson notes, "Rahel was still reluctant to admit to herself the extent to which this stood in the way of acceptance." For Varnhagen, assimilation was "real acculturation" through the ideals of the Enlightenment (102).

In 1827 the Varnhagens moved into a furnished apartment on Französische Straße which became the first location of Varnhagen's second salon and one in which her 
husband Karl Varnhagen now played a significant role. Previously serving just tea, Varnhagen now offered her guests elegant dinners (just as Florine Stettheimer and her sisters would do a century later in their New York salon). Along with encouraging conversation, Rahel's second salon featured literature and entertainment together with her ongoing emphasis on egalitarian and humanistic values. These accompaniments to conversation were necessary as "open houses" were also offered by established and wealthy Christian individuals so Varnhagen's salon needed to retain its appeal. Varnhagen was a vivacious hostess who was reputedly always generous, cordial and nonjudgemental.

In 1830 , the Varnhagens moved again, this time into a house on Mauerstraße, where they continued to host their salon in spacious, airy, light-blue rooms. Simple but sophisticated furniture was available for guests who had views of trees or the streets from the Varnhagen's windows. A piano-forte was accessible for musical entertainment. The guests who attended Varnhagen's second salon were a similar heterogeneous crowd which Varnhagen took great care to duplicate as this heterogeneity was essential to the character of her salon. However, these salon habitués tended to be academics and professionals who addressed political and scientific topics. Some of the renowned guests included the explorer and scientist Alexander von Humboldt, Eduard Gans who founded comparative jurisprudence and the writer and artist Bettine von Arnim. This salon also served an important role in creating a refuge which allowed guest to express liberal ideas, as the salon was free "from spies and censors that infiltrated the public sphere everywhere during the Period of Restoration [where] repression was so pervasive that few dared speak openly" (Tewarson 185). "The primary lack of freedom results from not 
being permitted to say what we desire and what we lack," Varnhagen declared in her diary. In it she also summed up the constraints Enlightenment thinkers faced and continued when she wrote: "To have freedom means simply to have what we need in order to be what we really should be; and to have what we really should have" (quoted in Tewarson 185-186). For Varnhagen, a lack of freedom constrained individual citizens and thinkers and prevented them from reaching their potential as she thought all people should. Keenly aware of the boundaries constraining women in mainstream society, Varnhagen sought to develop a measure of autonomy offered through her salon, and she achieved a certain degree of freedom within the semi-domestic/semi-public space of her own salon in her own home. Compared to the independence she enjoyed in her salon, the world outside afforded her very few opportunities for similar liberties. As a salonière, Varnhagen most certainly maximized her intellectual and creative potential through her encounters with her diverse group of guests while also granting freedom and permission to other marginalized groups who attended her salon to do so as well.

Varnhagen's second salon, then, can be seen as a vehicle to reassert her independence as a woman that had been somewhat diminished through her marriage with Varnhagen. For as the conductor of affairs in the salon, it was she (not her husband) who expertly and brilliantly engaged in conversation with her guests and re-established her competence in the role of hostess, conversationalist and intellectual. Moreover, Varnhagen assumed an important role in attending the salons of others (in contrast to Gertrude Stein and Florine Stettheimer, as we shall see, who were averse to attending other salon gatherings or parties). More than a mere presence at the salons of Amalie and Jacob Herz Beer or Dorothea Mendelssohn Veit Schlegel, as Eduard Devrient notes: 
"Rahel often enlivened the circle. In appearance and address plain and natural, speaking at all times frankly what her ready insight and warm feelings suggested, she yet was fully aware that her sayings were noted" (quoted in Bilski and Braun 32).

Varnhagen corresponded with many of her salon habitués, and the intellectual discourse and personal encounters initiated in her salon formed much of the basis of Varnhagen's epistolary work. In fact, her letters were reflective of salon discourse in their distinctive conversational style and these letters demonstrated "how intrinsic the principle of dialogue was to her entire project" (Bilski and Braun 30 ) which mirrored the way conversation actually unfolded amongst the habitués of her salon. Portending Varnhagen's eventual recognition as an influential woman writer and salonière of her generation, Alexander von Humboldt, alluding to Varnhagen's passing, wrote in a letter to Karl Varnhagen that she was "the ornament of her sex." Humboldt went on further to praise Varnhagen lavishly: "Such powers of the mind, and yet so genial, and so full of heart!" Similarly, Henriette Hertz observed: "the soul of the Jewish woman, thus awakened by emancipation, reached its highest development in and through Rahel" (quoted in Meyer 117).

With such high praise by her contemporaries, one may wonder why Varnhagen is not better known today but her lack of recognition may result from the fact that, as Bertha Meyer notes, "her undoubted genius was for human contacts." It was her engagement with habitués of the salon which led to encounters with so many diverse and interesting people. Varnhagen's detailed letters which were inextricably linked to her salon interactions provide insight into the social position of women and the limitations they faced in the late eighteenth and early nineteenth-centuries. These interactions resulted in 
the plethora of letters which contained insights about Varnhagen's socially progressive beliefs and which consequently encouraged younger women, such as writer Fanny Lewald, to write about social injustice and prejudice a generation later (Goodman 139). Varnhagen presaged Lewald's feminist thinking when she wrote of the equality between the sexes which was central to her belief. She described her relationship to her husband and wrote: "I acknowledge no relationship to be free and beautiful it if restricts me," and she continued: "if it makes me lie or deny my nature what is possible and necessary to it" (quoted in Key 168). "There is a universe," she wrote in another letter: "in it we develop. And it matters not at all what fate is ours, when we have arrived at the perception that development is our fate" (quoted in Key 133). Thus, Varnhagen endorsed the belief that all individuals were empowered through personal development independent of ethnicity or gender. As further evidence of her belief in equality she declared to her sister: "Nature is terrible only in that a woman can be abused and forced to produce a human being against her pleasure and will. This great wrong must be made right again through human efforts and institutions and shows how much the child belongs to the woman" (quoted in Tewarson 216). Varnhagen's letters were able to move "the hearts and minds of women" in an unconventional feminist way.

Not only did Varnhagen exert a great influence on those she met, but also her salons existed when "the strict feudal code governing all aspects of human relations were beginning to give way to a freer, more egalitarian mode of interaction" (Tewarson 44). As a vehicle for social progress and change, her salon promoted egalitarian ideals as evinced by her letters, aiding in Jewish assimilation and acceptance within a largely antiSemitic society, while also allowing an accomplished woman to gain credibility in a 
semi-public sphere. Her salon afforded her a platform for exposing her intellect, attaining a degree of social recognition and validation for her existence as a doubly marginalized woman and that in itself was an important success. Her efforts at realizing equality of social classes, ethnic groups, genders and religions may have been limited in her lifetime to the semi-private space of her salon, but her salon did hail the egalitarian and intellectual goals of future generations of women and Jewish salonières, as we shall see now by turning to the Stettheimer sisters in New York. 


\section{2: Florine Stettheimer's Salon: Social Harmony}

Across the divide of a century, the Stettheimer family of New York City, like the Levins in Berlin, were a part of the elite German-Jewish nobility, affording the family a privileged lifestyle on the Upper West Side. Interestingly, as biographer Barbara J. Bloemink writes, Florine Stettheimer (1871-1944) was brought up in an environment almost entirely comprised of women as her family consisted of her mother along with her older sister Carrie and younger sister Ettie as well as her nine aunts on her mother's side. It was the abandonment by their father and the move of the two older siblings to the West Coast which led to the tight bond between Florine and her two sisters resulting in their promise to each other that they would never leave their mother - evidence of the Stettheimers' leanings towards the Varnhagen sociability and its pursuit through salon culture.

Where the salon was a space of assimilation for Varnhagen, as I have argued, the twentieth-century salon of Florine Stettheimer and her sisters bridged the gap between Florine's desired social fluidity and harmony amongst different races and religions and the reality of racial divisions in American society as well as being central to Florine's life as an artist. Thus, as Bilski and Braun (131) argue, the Stettheimers formed their own elite crowd in their salon, creating a space where the sisters met and interacted with the intellectual and cultural elite of the day. In other words, as I propose, the salon was the thread that tied together the women of this Jewish family and permitted their assimilation into society in a semi-public realm, while also championing non-traditional feminine roles and allowing them to exert power over their invited guests and engage in stimulating, progressive society. As a doubly marginalized Jewish woman like 
Varnhagen, Florine Stettheimer found in the salon a space that allowed her a measure of freedom to devote her talent and energies to her art. Thus, as I shall argue here, the salon was a vehicle for her assimilation into the larger society, as it was for Varnhagen, although Florine embraced the non-traditional, modernist life and identity of the early twentieth century. An acceptance of diverse races was woven into the fabric of Stettheimer's salon, as it was for Varnhagen's, while Florine also used her salon and her art to flirt with the crossing of sexual boundaries.

Similar to Varnhagen, the Stettheimers' inherited wealth allowed Florine to lead a non-traditional life - marriage was an option but not a necessity since she did not require support from anyone outside of the family and this in turn enabled her to pursue art, sociability and salon culture. Varnhagen married late in life and never had children but Florine never married at all and instead cultivated intimate friendships with men and women. It is important to note that a patriarch was absent from the Stettheimer family since deserting them when Florine was young but the sisters flourished in his absence just as Rahel Varnhagen had blossomed after her father's death. In fact, Florine's mother encouraged her daughter to become independent and seek professional education at the Arts Students League in New York and this reflected the well-established Jewish appreciation for education. Furthermore, some of her diary entries and poetry suggest that Florine, like Varnhagen, fought against the stereotyping of women (her ironic painting The Cathedrals of Art (1942-44) [Fig.1], for example, represents a pantheon of great male artists with the women positioned on the periphery of her composition).

The passing of a full century, as well as the change of location from Germany to America, did much to grant Florine a significantly greater measure of freedom compared 
to Varnhagen's in early nineteenth-century Berlin. In fact, by 1920 , Jews represented $29 \%$ of New York City's growing population. Still, there was a religious indifference reminiscent of Varnhagen's, illustrated when Bloemink observes: "Throughout her life, Florine maintained an ambivalent attitude not only toward organized religion but also toward any kind of imposed ethics or restraints" (8-9). Florine makes oblique reference to this ambivalence in her painting Portrait of My Sister Ettie Stettheimer (1923) [Fig. 2], which depicts Ettie sprawled on a red cushion and floating in space beside a decorated Christmas tree which is in flames. The Stettheimers were assimilated Jews and only Florine's grandfather was a practicing Jew; as a child Florine was more likely to accompany her Irish nurse to church services than practice any Jewish religious ritual. Similar to family of Varnhagen and other upper-class German-Jews, Florine's family did not actively engage in Judaism but rather related to their faith as a social identity as evidenced by the entire salon culture with its appreciation of intellectualism and discourse as a secularized form of Jewish religious tradition as discussed earlier. The Stettheimers' fortune and their secular beliefs were aligned with their desire to live independently and to freely express their intellectualism as they did in their salon where they promoted a harmonious, sociable confluence of intellectuals, regardless of religion. Their wealth and life of privilege buffered them from some of the anti-Semitism which other Jews in lower classes experienced in New York, but Florine, unlike Varnhagen, never went so far as to deny her religious heritage. In fact, she set clear limits, and despised "fashionable Jews" who chose baptism as a hypocritical means to fit into society and, on one occasion, refused an invitation to exhibit her artwork because the venue was a church that was known for baptizing Jews (Bilski and Braun 130; Bloemink 98-99). 
Still, the Stettheimer salon was a vehicle for assimilation for the Stettheimers and for other marginalized intellectuals and artists confronted with racial and sexual prejudice in New York, of which Florine was deeply aware. For example, her painting Lake Placid (1919) [Fig. 3] depicts her family's summer retreat in Lake Placid where the majority of residents were Protestant. The painting represents many of New York's leaders in the avant-garde movement of varying ethnic backgrounds who were also habitués of the Stettheimers' salon enjoying the pleasures of a lakefront cottage. However, at the early part of the nineteenth-century the area of Lake Placid witnessed, as David Tatham observes: "casual and institutionalized religious, racial, and class bigotry" (22). Amongst others the painting features: Peruvian Ambassador Javier Alvarez who was Catholic, Rabbi Stephen Wise who was a Reform Jew, Edwin Robert Seligman who was a nonobservant Jew and Elizabeth Duncan who was an atheist and a modern dance instructor. Since none of these individuals depicted would have been accepted as suitable members at the exclusively Protestant Lake Placid Club, Florine creates a world in her painting that is similar to her salon where her friends and colleagues were accepted irrespective of religion and race. Florine's painting is distinctly critical of the prejudices of Lake Placid, embedding a deeply ironic commentary in her painting's title. The title alludes to the racism and classism of the Adirondacks' Lake Placid which extended to encompass the racism found in America.

"New York, in the years before and during World War I, was the site of several famous private salons, where the provincial attitudes of the nineteenth-century city were challenged by new ideas, ranging from avant-garde art and music to social reform, psychoanalysis, and literature," write the co-curators of the Florine Stettheimer exhibition 
at the Whitney Museum of American Art, Elizabeth Sussman and Barbara J. Bloemink (43). The Stettheimers' salon was located in a brownstone apartment at 102 West Seventy-Sixth Street in 1914 and later, in 1926, at Alwyn Court on West Fifty-Eighth Street (Bilski and Braun 126). In particular, the Stettheimer salon varied from the other New York salons at the time, especially those in Lower Manhattan, in that it was more elitist and proper than others; it was as Bilski and Braun observe: "a distinctly uptown affair, a theater of the world where propriety and appearances were maintained, if knowingly staged" (128). Art critic and friend of the Stettheimers Henry McBride related that guests from Greenwich Village would occasionally be present but "if there was too much Eighth Street in his manner he was unlikely to reappear" (quoted in Bilski and Braun 128). Thus the Stettheimer gatherings were a "throwback to seventeenth-century sociability" (Bilski and Braun 128), where, similar to Varnhagen's first salon, the art of conversation was a priority.

Even amongst their closest friends, the Stettheimers always had an air of nobility, formality, and femininity with which they consistently kept up a façade. Florine Stettheimer referred to this as her "pink light" in her poem "Occasionally":

When I meet a stranger-

Out of courtesy

I turn on a soft

Pink light

Which is found modest

Even charming

It is a protection 
Against wear

And tears

And when

I am rid of

The Always-to-be-Stranger

I turn on my light

And become myself

(Stettheimer and Waste, Crystal Flowers 42)

This poem reveals not just her guarded, private nature but also her adherence to her own standards of what was right and proper. Florine's first biographer, Parker Tyler, also notes that if "an inadmissible topic came up" (93), Florine would quickly change the topic of conversation or leave the room and this was further evidence of her desire to uphold proper etiquette in her salon. Unlike the public sphere, the semi-public environs of the salon was Florine's construct, as was she herself, since she created her own façade and exerted her influence on the salon.

The Stettheimer sisters hand-selected the guests and usually drew upon an intellectual and avant-garde crowd, in addition to Jewish family and friends. The numerous habitués of the Stettheimer salon included artists, writers, photographers, singers, dancers, and even scientists. Painter and photographer Edward Steichen, sculptors Gaston Lachaise and Elie Nadelman, avantgardist painters Marcel Duchamp, Albert Gleizes, Charles Demuth, and Marsden Hartley were among the artists who regularly frequented the salon. As well, photographers Alfred Stieglitz and Carl Van Vechten, and author Sherwood Anderson were habitués (Bilski and Braun 126). Art 
critics Paul Rosenfeld and Henry McBride also frequented the Stettheimer salon and McBride had much influence in the art world. His appreciation of Florine's art was beneficial to Florine's notoriety in the New York art scene which in turn added to the cachet of her salon.

Mirroring Varnhagen's Berlin salon, the list of invited guests included intellectuals and cultural leaders representing a wide range of significant New York art establishments. As influential salonières the Stettheimer sisters brought together artists and those who could affect their careers. As history has shown, the Stettheimers' habitués became much better known than their hostesses as many on Florine's roster of salon habitués are still regarded as influential and important figures who profoundly influenced culture. Thus, the salon satisfied Florine's need for personal intellectualism, cultural stimulation and, additionally, the social networking of the salon helped develop its importance as a cultural institution.

Furthermore, the Stettheimer salon was not just distinguished from other more bohemian New York salons (such as Mabel Dodge's, or L'Alelia Walker's, or The Little Review Circle) by its elitism, but according to McBride, novel creative ideas flourished that were eventually embraced by others so that the socially subversive salon was evidently quite influential. McBride, writing in an article in the magazine Town and Country, declared that the Stettheimers "had considerable to do with the shaping of the intellectual and artistic impulses of the past... [and were where] hardy ideas were put into words which echoed sooner or later in other parts of the city" (quoted in Bloemink 95). Art critic Rosenfeld, in an article about Florine published just following her death stated that her salon "will figure in all accounts of the modern art movement in New York. It 
was such a genuine gathering-place of its sort; not one of those which, in wit's words, 'set out to be salons and succeed only in becoming restaurants." He continues:

Artists indeed voluntarily went there and not at all merely

because of the individualities of the trio of women and their

tasteful hospitality. They went for the reason that they felt

themselves entirely at home in their company (Rosenfeld 637).

Additionally, the Stettheimer salon was an important vehicle for Florine which enabled her to exercise her considerable power and influence in the cultural fabric of New York of that time. Discrepancies in the accounts of Stettheimer gatherings as given by their guests lead to differing opinions on the influence of the salon. Apparently, author Virgil Thomson was very dismissive of any influence that the Stettheimer salon may have had and suggested that it was simply a venue for amusement; however, the salon did help to expand social boundaries in terms of gender, class, and race in its time period because it was so inclusive and supportive of marginalized individuals. The Stettheimer salon although elitist and less involved in breaking class barriers did effectually help to overcome gender and racial boundaries then upheld in New York society by being a model of inclusiveness.

Although to some extent Florine shared hosting duties with Carrie and Ettie, she took sole responsibility for decorating the interior of their New York apartment. The décor was reminiscent of a rococo style: formal, ornate and decorative as it had red taffeta curtains and gilded furniture which evoked an historical French salon. Bilski and Braun indicate that this style helped to create an environment conducive to "social fluidity" where the refined wealthy aristocratic segment of society could meet with the 
avant-garde artists and thinkers. Moreover, within this elaborate decorating scheme was a peculiar Stettheimer aesthetic referred to by Bilski and Braun as "a Jewish rococo" (135) [Fig. 4]. The feeling as described by salon attendees was that of being at home and the Stettheimers enhanced this by providing great hospitality especially by offering elaborate meals.

Although the Stettheimer salon was home to the new and avant-garde of New York, Florine's chosen traditional, feminine décor was aristocratic in character which was at variance with the nature of the progressive concepts that were expressed in her salon. Cécile Whiting comments that the inside of the Stettheimers' apartment provides a "stage upon which an unorthodox family and their friends could enact the public gestures of proper, upper-class social mores - all the while revealing nothing about their own private desires" (36). In this the entire apartment and salon were a staged construct - an artistic effort - upon which Florine, the artist, was enacting the role of the salonière on a stage. Just as Varnhagen orchestrated intellectual discourse conducive to optimizing a setting that encouraged stimulating conversation, so Florine created her salon as a work of art. Thus her Alwyn apartment [Fig. 5], which included the furniture she herself made, was an artistic installation, as Whiting observes: "The decor of Florine's various domestic spaces and the configuration of her family [consisting of a mother and her three daughters] redefined the terms of the conventional home"; the Stettheimer home and salon showcased a design aesthetic that was in diametrical contrast to conventional domestic aesthetic which was meant to "serve as the backdrop for the bourgeois family in which women assumed the role of wife and mother" (36). It is understandable that Florine's décor was unconventional given the unconventional Stettheimer family 
dynamic that arose from its matriarchal nature especially as Florine eschewed the traditional feminine wifely role.

Within her salon gatherings Florine said little and yet McBride referred to her as "genii loci" within her influential salon (10). Moreover, Ettie suggested in the introduction of Crystal Flowers, a small collection of Florine's poetry, that it was Florine's presence which made their salon such a great success (iv). Florine was an observer who also used the salon to display her own artwork, a practice Florine describes in her 1917 poem "Our Parties":

Our Parties

Our Picnics

Our Banquets

Our Friends

Have at last a raison d'être

Seen in color and design

It amuses me

To recreate them

To paint them.

(Stettheimer and Waste, Crystal Flowers 82).

Indisputably, the Stettheimer salon provided Florine with inspiration for her art since her guests and her salon became subject matter for her paintings. In her poem, the salon appears to have been secondary in importance to her artwork which was inextricably bound to the salon as both a raison d'être, as it could be used for her art, and as it provided her a social realm from which to observe the interactions of her guests which 
she alluded to in paintings. This complex interrelation is summed up when Tyler's refers to Florine as an "art hostess" (71), since her paintings were situated within her family's salon, providing both entertainment and a source of stimulation for salon conversation. Florine's presence as "art hostess" sustained the salon.

According to Bloemink, Florine's life spanned two very different centuries and she witnessed an evolution of female gender roles: a traditional one and one aligned with a more contemporary "New Woman" of the modern era (13). Florine playfully donned aspects of both according to her own aesthetic. Her family circumstances enabled her to enjoy this freedom of choice although marginalized by society at large as Jew and a woman. Her personal freedom arose from the situation which resulted from abandonment by their father and the subsequent marriages of an older brother and sister which left the Stettheimers as an entirely feminine household. They seemed quite content with their circumstances as by all accounts the family lived as they pleased without censure, pressure or desire to conform. For instance, Florine and her sisters never married although men tried to court them, even at times proposing marriage, but Florine is described "as dedicated to the unmarried state as she was to art" (Tyler 117). Tyler goes so far as to say that "Carl Van Vechten solemnly terms the Stettheimer sisters "virgins by desire." As conventional married women they would have been expected to suppress their instincts towards independence and they would have been subservient to husbands and involved in child-rearing which would have impacted on their freedom. Instead the women's instinct was towards the freedom that resulted in liberation from traditional roles. 
Florine's unconventional position as a Jewish woman granted her the opportunity to construct her salon with her sisters following their own particular goals. She created an empowering socially flexible role to participate in artistic and intellectual society. Bloemink argues that "Unlike many other contemporary women in her situation (including her sisters), Florine was unwilling to settle for a life of luxurious eccentricity and frivolous socialization" (235). Instead, Florine opted for a life dedicated to her work as a painter and, as well, as a salonière which ultimately led back to her artwork as it was in opening the Stettheimer home as a salon that Florine obtained new ideas for her art. Her art was imbued with her ideas about society. The overarching themes in her work as evidenced by the subject matter of her many paintings is a commentary on contemporary New York society.

The extent to which Florine demonstrated her struggle to liberate herself from traditionally feminine roles and play with the crossing of sexual boundaries was revealed in her salon and paralleled in her self-portraits. These self-portraits illustrate the persona she constructed for herself just as she constructed the artistic atmosphere of her salon and conducted herself within it. In the painting Self-Portrait in Front of Chinese Screen (1912-14) [Fig. 6], Florine deemphasizes her femininity and holds a palette and brushes revealing the centrality of her self-image as artist. Her Self-Portrait (1915-16) depicts her as nude, and a year later, Florine daringly references this self-portrait in her 1917-19 painting Soirée (which appears as the frontispiece to this essay). Her self-depiction as an iconic nude takes up a large part of the composition of Soirée yet her presence in Soirée is in the format of the self-portrait and also reflects the more distanced role she enacted in the Stettheimer salon. Florine reiterates this ambiguity in Portrait of Myself (1923) 
[Fig.7], where an artist's beret highlights her professional career as a painter and is a leitmotif seen again in the undated Painter and Faun, where Florine's sexuality is countered by the inclusion of a palette and paintbrush signifying that although she is a woman she wears male clothing and wants to be perceived as an artist. Florine often portrayed herself in androgynous roles to remind the viewer that her feminine self was second to her artistic occupation. Autonomy was possible as she was an avant-garde salonière purposely positioned away from the conventional life of a bourgeois woman. The mixing of genders found within her paintings and salon is essential and is evident in Florine's portraits of others such as Portrait of Carl Van Vechten and Henry McBride, Art Critic both dating from 1922 [Figs. 8 \& 9]. Both men are depicted in a feminized, prissy posture having stylized, curvilinear silhouettes with very delicate hands and feet. These paintings illustrate the importance of defying traditional gender roles both in art and in the salon.

The role of avantgardist Marcel Duchamp as a frequent guest, close friend and subject for several paintings was key in this gender-bending play. Just as the Stettheimer salon crossed racial and gender boundaries and Florine herself crossed liberal and traditional boundaries in her self-portraits, so did Duchamp. In his persona of Rrose Sélavy first captured in a 1921 photograph by artist Man Ray, Duchamp dressed up in women's clothing similar in appearance to Florine herself. "Rose" was a common name for New York Jews at the time while "Sélavy" phonetically evoked the Jewish surname Levy. While it was common at this time for Jewish immigrants arriving in New York from Europe to change their names, Duchamp reversed this practice with his incarnation as "Rrose Sélavy" and gave himself a cross-gendered Jewish identity: an interesting 
gesture considering the anti-Semitism that existed in some circles. Both Florine and Duchamp grappled with gender and racial boundaries and empowered themselves as artists to create a new social construct in defiance of the rules of mainstream society.

In the canon of modern art in America, Florine's contribution to the art world has begun to attract attention after being ignored, like Varnhagen's contribution to literature. Jutta Koether, in an article in Artforum magazine, states that Florine "had an unorthodox versatility, an ability to have a noncareer in art and still be at the center of things, an attractor and a trigger of conversation" (17). It was this ability to attract attention and to incite conversation which proved successful in the establishment of her family's salon and led to its success in developing a sociable community for New York's many marginalized artists (as alluded to in the epigraph that opens this essay, the importance of sociability was integral to the salon environment). Fortunately for the Stettheimers (just as with the female-dominated Varnhagen family), patriarchal notions that a woman's place was with husband and family did not apply and Florine could devote herself to her own artistic interests.

The Stettheimer's salon along with Florine's Beaux-Arts apartment studio (where her sisters were welcomed by invitation only) was used as Florine's private gallery to display her paintings in accordance with her personal taste: evidence of the use of the salon to facilitate her personal goals as an artist. Due to her friendships with avant-garde artists such as Duchamp, Steichen, Lachaise, and Gleizes, and the presence of the influential art critic McBride, Stettheimer had a steady flow of critical and influential viewers without ever attempting to have her work formally admitted to an art gallery. The ease of displaying her work within the Stettheimer home provided Florine a forum and 
critical feedback and the approbation of her invited guests. Florine rarely exhibited and, ultimately, did not support herself through her art as she was so attached to her work that she would not part with her paintings. Whiting argues that because Florine worked privately in her studio and only exhibited her art to special friends Florine "formed her professional identity as a woman artist as much by her aesthetic taste as by the seclusion of that taste within the domestic interior" (37). Besides painting portraits of artists and famous individuals who attended her salon, Florine included her illustrious salon guests and friends such as Stieglitz, Lachaise, Avery Hopwood, Leo Stein and Maurice Sterne and many salon habitués in most of her other artwork as found in Soiree (1917 - 1919) and they were also depicted in paintings such as Lake Placid and Asbury Park South (1920).

Aside from her supporters inside her salon, Florine's work was largely seen rather derogatorily as "feminine." Her portraiture, in particular, was not well-received by mainstream critics because of her distinctive aesthetic. In 1931, Florine's acquaintance, Marsden Hartley favourably reviewed her work in the magazine Creative Art; however, his labelling of Florine's paintings as "delicate" and "fanciful" (quoted in Bloemink 174) and Hartley's emphasis on overtly feminine characteristics as well as the "overall description of her work as 'quaint' not only positioned her outside the norm but distinctly ghettoized her within her gender," as Bloemink observes (175). Even her art critic friends such as Rosenfeld and $\mathrm{McBride}$, who gave her praise, still deemed her work to have an overarching feminine quality. This implicitly pejorative assessment of Florine's art continues to surround her even today, for the 'feminine' is often equated with being decorative, delicate and pretty but superficial. Florine, as evidenced by her body of work, 
remained steadfast and true to her particular artistic aesthetic. Unconventional and doubly marginalized, Florine's life was an artistic construct that was enabled by her salon. Her eccentric life, her personal style, her subject matter and her art: all were Florine's artistic creations that culminated and flourished in the salon. Ultimately, the sense of being an outsider as a German-Jewish woman who lived in a male-dominated society bound up within the patriarchal world of art afforded Florine a particular perspective along with an intellectual and open-minded elite circle in which she could share her ideas and celebrate her vision of gender, racial and social harmony. 


\section{The Salon as an Alternative Space}

Subjected to the double marginalization of being born as Jews and as women, as I have argued in this essay Rahel Varnhagen and Florine Stettheimer successfully constructed an alternative social sphere in their own homes - ironically, traditionally domestic domains - to overcome limitations of the traditional roles deemed suitable for Jewish women as dictated by society. It was in this domestic setting, so often the only purview of women, where they exerted their control and found their empowerment which, because of the ambitious women they were, facilitated the construction of their own society. Their semiprivate, semi-public salons each had their own strengths and limitations, as Bilski and Braun have observed about the salon in general: "Privileged but restricted, salonières could merely bring the public world into their private domain, temporarily lessening the divisions between the two" (15).

Through the salon, Rahel Varnhagen and Florine Stettheimer found the advantageous gateway they sought into society. They could not gain admittance to a world largely closed off to Jewish women but as salonières they could admit to their own homes artists and intellectuals and choreograph free association that defied the sociability of mainstream society. For Varnhagen the salon was the social location she longed for and the one space where her vision of a universal and egalitarian world could exist even if mainly confined to the home. Hannah Arendt articulates this and writes: "The 'salon' is Rahel's social opportunity and justification. She finds it the foundation upon which she can live, the space wherein she is socially recognized. The salon is her social reality" (28). The same can be said about Florine Stettheimer, but additionally, Florine used her salon as her stage and as a venue to gain admittance to the art world and its cultural 
society. Although Florine assumed a more deliberately passive role in her salon as an observer she cleverly staged herself through her artwork, in contrast to Rahel Varnhagen's desire to be central to all conversation. Varnhagen's salon gave her a powerful and influential voice, though not necessarily a Jewish voice. Each of these notable women was a product of her time, however, and while Florine accepted her Jewish identity more than Varnhagen, she lived in a vastly different society with more options for women and increased acceptance for ethnic differences (though anti-Semitic sentiment persisted even amongst the New York avant-garde).

The socially fluid role of the salonière allowed the two women to create visions of a society where all social classes and ethnic groups were accepted with more tolerance, where men and women were considered equal and where Jews and non-Jews were engaged in conversation. In Florine's salon even sexual differences were accepted and celebrated although individuals who expressed sexual differences were still marginalized in society at large but the community she had designed to suit only herself was reflected in her paintings, her set designs and her everyday life. Ultimately, for Rahel Varnhagen and Florine Stettheimer the salons were their creations, their ego-centric universes that dominated their respective lives and identities, and allowed them to draw important figures of their era into its orbit of social and cultural renovation. 


\section{Works Cited}

Arendt, Hannah, Kohn, J., \& Feldman, R. H. (2007). The Jewish Writings. New York:

Schocken Books.

Arendt, Hannah. Rahel Varnhagen : the Life of a Jewish Woman. New York: Harcourt Brace Jovanovich, 1974.

Bailey, Bradley. "Rrose of Washington Square : Marcel Duchamp, Fanny Brice, and the Jewish Origins of Rrose Sélavy." Source Notes in the History of Art. 27.1 (2007): $39-45$.

Barnouw, Dagmar. "Origin and Transformation: Salomon Maimon and German-Jewish Enlightenment Culture.” Shofar 20.4 (2002): 64-82.

Benhabib, Seyla. "The Pariah and her Shadow: Hannah Arendt's Biography of Rahel Varnhagen." Political Theory 23.1 (1995): 5-24.

Bilski, Emily and Emily Braun. Jewish Women and Their Salons. New Haven and London: Yale UP, 2005.

Bloemink, Barbara J., and Florine Stettheimer. The Life and Art of Florine Stettheimer. New Haven: Yale University Press, 1995.

Burroughs, Betty. Rev. of Florine Stettheimer. By Henry McBride. The New York Times. 20 April 1947: BR16.

Chesney, Duncan McColl. "The History of the History of the Salon." Nineteenth Century French Studies 36.1.2 (2007): 94-108.

Cohn, Norman Rufus Colin. Warrant for Genocide : The Myth of the Jewish 
World-Conspiracy and the Protocols of the Elders of Zion. New York: Harper \& Row, 1967.

Corkhill, Alan. "Female Language Theory in the Age of Goethe: Three Case

Studies." Modern Language Review 94.4 (1999): 1041-1053.

Daley, Margaretmary. Women of Letters : A Study of Self and Genre in the Personal Writing of Caroline Schlegel-Schelling, Rahel Levin Varnhagen, and Bettina von Arnim. Columbia, S.C.: Camden House, 1998.

Dauber, Jeremy Asher. Antonio's Devils: Writers of the Jewish Enlightenment and the Birth of Modern Hebrew and Yiddish Literature. Stanford, Calif.: Stanford University Press, 2004.

French, Lorely. German Women as Letter Writers, 1750-1850. Madison N.J.: Fairleigh Dickinson University Press, 1996.

Goodman, Dena. "Enlightenment Salons: The Convergence of Female and Philosophic Ambitions" Eighteenth-Century Studies 22.3 (1989): 329-350.

Goodman, Kay. "Poesis and Praxis in Rahel Varnhagen's Letters." New German Critique 27 Women Writers and Critics (1982): 123-39.

Graves, Donna. “'In Spite of Alien Temperature and Alien Insistence': Emily Dickinson and Florine Stettheimer." Woman's Art Journal 3.2 (1983): 21-27.

Hahn, Barbara. The Jewess Pallas Athena: This Too a Theory of Modernity. Princeton, N.J.: Princeton University Press, 2005.

Harth, Erica. Cartesian Women: Versions and Subversions of Rational Discourse in the Old Regime. Ithaca, N.Y.: Cornell University Press, 1992.

Hertz, Deborah Sadie. How Jews Became Germans : The History of Conversion and 
Assimilation in Berlin. New Haven: Yale University Press, 2007.

Herzog, Dagmar. "Carl Scholl, Gustav Struve, and the Problematics of Philosemitism in 1840s Germany: Radical Christian Dissent and the Reform Jewish Response." Jewish History 9.2 (1995): 53-72.

Humboldt, Alexander von. "To Varnhagen von Ense." 9 March 1833. Letter XII of Letters of Alexander von Humboldt, Written Between the Years 1827 and 1858, to Varnhagen von Ense. London: Trübner and Co., 1860.

Kale, Steven D. "Women, the Public Sphere, and the Persistence of Salons." French Historical Studies 25.1 (Winter 2002): 115-148.

Key, Ellen. Rahel Varnhagen : A Portrait. Westport, Conn.: Hyperion Press, 1976.

Koether, Jutta. "Boho Rococo: Interview with Curator Elizabeth Sussman on the Works of Artist Florine Stettheimer." Artforum 22 June 1995: 17.

Krauss, Rosalind E. Bachelors. Cambridge, Mass.: MIT Press, 1999.

Landes, Joan B. Women and the Public Sphere in the Age of the French Revolution. Ithaca: Cornell University Press, 1988.

Leibovici, Martine. "Arendt's Rahel Varnhagen: A New Kind of Narration in the Impasses of German-Jewish Assimilation and Existenzphilosophie." Social Research 74.3 (2007): 903-922.

Liu, Jui-Ch'i (Rachel). "Carnival Culture and the Engendering of Florine Stettheimer." Diss. Bryn Mawr College, 1999. Locke, Jill. "Shame and the Future of Feminism." Hypatia 22.4 (2007): 146-162. McBride, Henry. Florine Stettheimer. New York: The Museum of Modern Art, 1946. Merwin, Ted. In Their Own Image: New York Jews in Jazz Age Popular Culture. New 
Jersey: Rutgers University Press, 2006.

Meyer, Bertha. Salon Sketches; Biographical Studies of Berlin Salons of the Emancipation. New York: Bloch, 1938.

Nochlin, Linda. "Florine Stettheimer: Rococo Subversive." Women, Art, Power and Other Essays. New York: Harper \& Row, 1988. 109-135

Pickett, Terry H. The Unseasonable Democrat : Karl August Varnhagen Von Ense (17851858). Bonn: Bouvier, 1985.

Rosenfeld, Paul. "Art: The World of Florine Stettheimer." The Nation 4 May 1932: 522523.

Rosenfeld, Paul. "Florine Stettheimer." Accent Anthology: Selections from Accent, a Quarterly of New Literature, 1940-1945 1946: 636-640.

Smith, Roberta. "The Very Rich Hours of Florine Stettheimer." The New York Times 10 October 1993: Late Edition - Final 93.

Smith-Rosenberg, Carroll. Disorderly Conduct : Visions of Gender in Victorian America. New York ; Oxford: Oxford University Press, 1986.

Solomon, Deborah. "Florine Stettheimer at the Whitney, Finally." The Wall Street Journal 18 July 1995: A12.

Steinberg, Michael P. "Hannah Arendt and the Cultural Style of the German Jews." Social Research. 74.3 (Fall 2007): 879-903.

Stettheimer, Florine. Florine Stettheimer; an Exhibition of Paintings, Watercolors, Drawings. New York: Columbia University, 1973.

Stettheimer, Ettie. Memorial Volume of and by Ettie Stettheimer. New York: Alfred Knopf, 1951. i-iv. 
Introduction. Crystal Flowers. New York, 1949.

Stettheimer, Florine, and Henrie Waste. Crystal Flowers. New York, 1949.

Tatham, David. "Florine Stettheimer at Lake Placid, 1919: Modernism in the Adirondacks." American Art Journal 31.1.2 (2000): 5-31.

Tewarson, Heidi Thomann. Rahel Levin Varnhagen : The Life and Work of a German Jewish Intellectual. Lincoln: University of Nebraska Press, 1998.

The Stone Edition Tanach. Rabbi Nosson Scherman, ed. New York: Mesorah Publications Limited, 2000.

Tyler, Parker. Florine Stettheimer: A Life in Art. New York: Farrar, Straus, 1963. Weissberg, Liliane. "Stepping Out: The Writing of Difference in Rahel Varnhagen's Letters." New German Critique. 53 (1991): 149-162.

Weissberg, Liliane. "Turns of Emancipation: On Rahel Varnhagen's Letters." Cultural Critique 21 (1992): 219-38.

. "Writing on the Wall: Letters of Rahel Varnhagen." New German Critique 36 (1985): 157-73.

Whiting, Cecil. "Decorating with Stettheimer and the Boys." American Art. 14.1 (2000): 24-49.

Wistrich, Robert S. Antisemitism : The Longest Hatred. London: Thames Methuen, 1991. 


\section{Appendix}

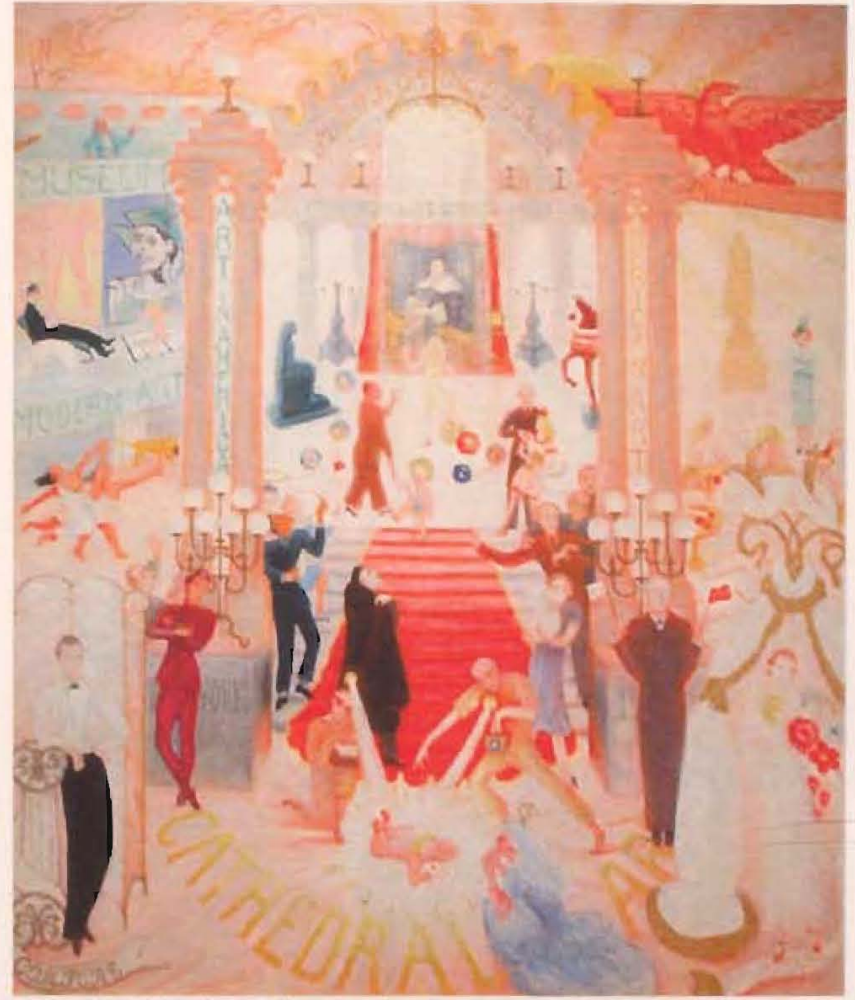

Fig. 1. Florine Stettheimer, The Cathedrals of Art (1942-44), 60 x 50 in. Metropolitan Museum of Art, New York.

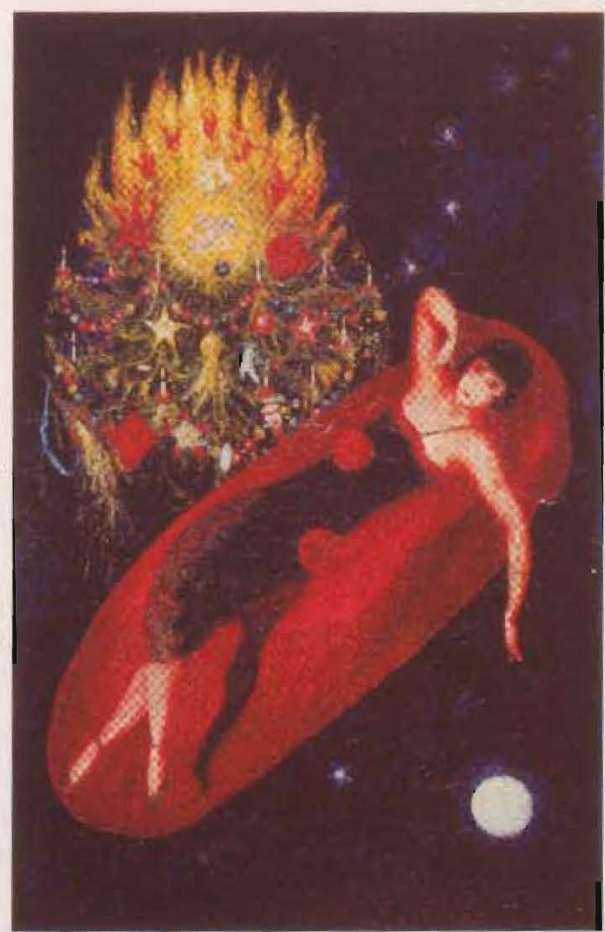

Fig. 2. Florine Stettheimer, Portrait of My Sister Ettie Stettheimer (1923), $40 \times 26$ in. Columbia University, New York. 


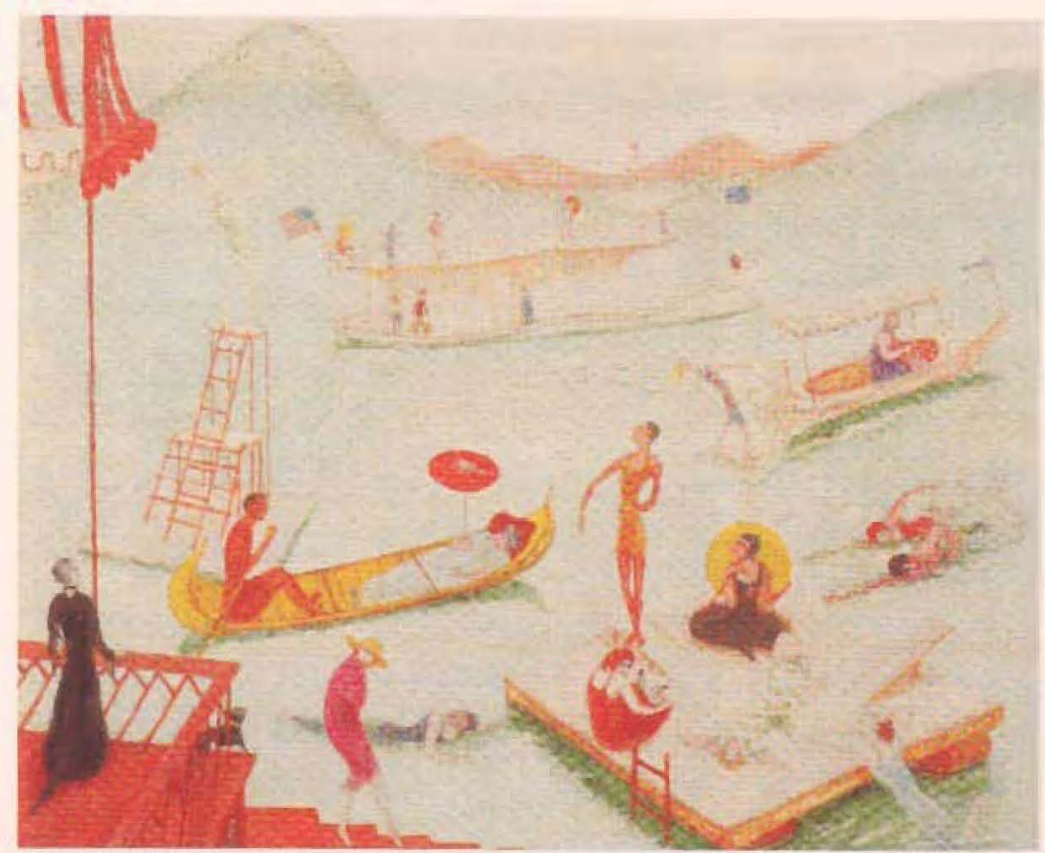

Fig. 3. Florine Stettheimer, Lake Placid (1919), 40 1/8 x 50 1/8 in. Museum of Fine Arts, Boston.

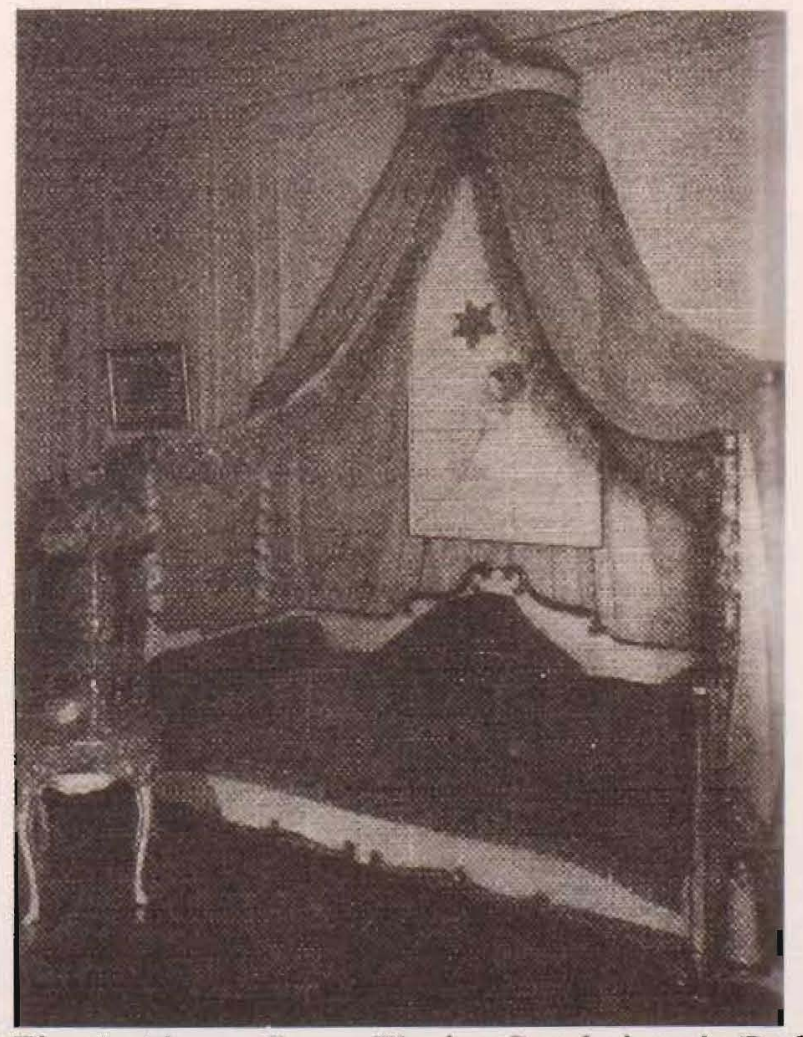

Fig. 4. Alwyn Court, Florine Stettheimer's Bed. Florine Stettheimer papers, Rare Book and Manuscript Library, Columbia University, New York. 


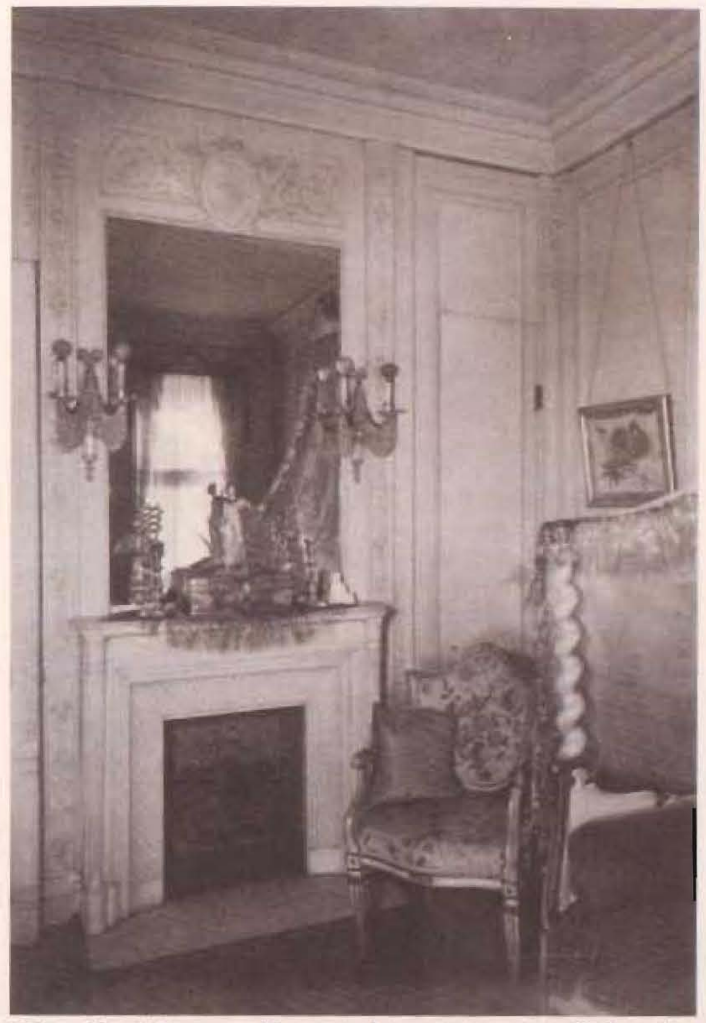

Fig. 5. Alwyn Court Apartment of the Stettheimer Family.

Florine Stettheimer papers, Rare Book and Manuscript Library, Columbia University, New York.

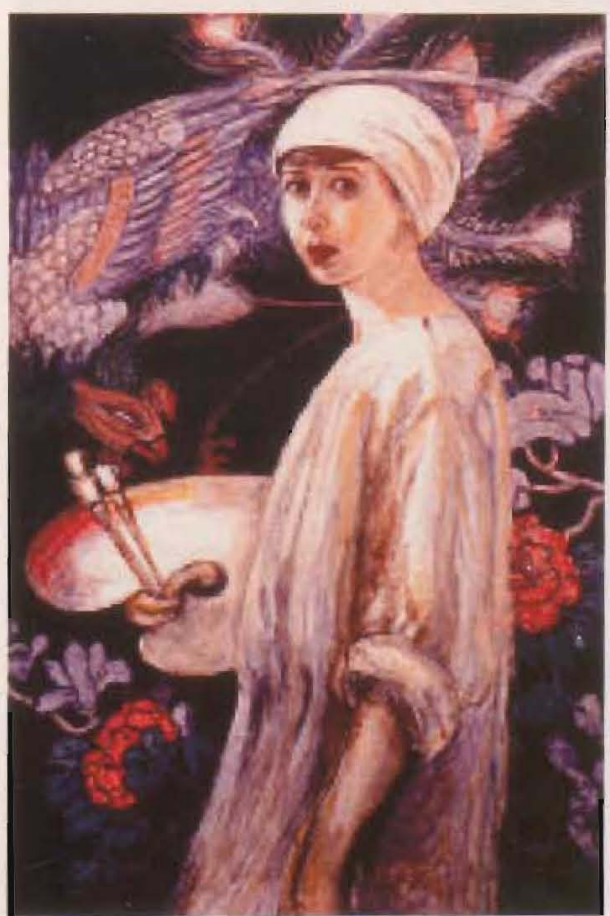

Fig. 6. Florine Stettheimer, Self-Portrait in Front of Chinese Screen (1912), 39 3/8 x 31 3/4in. Columbia University, New York. 


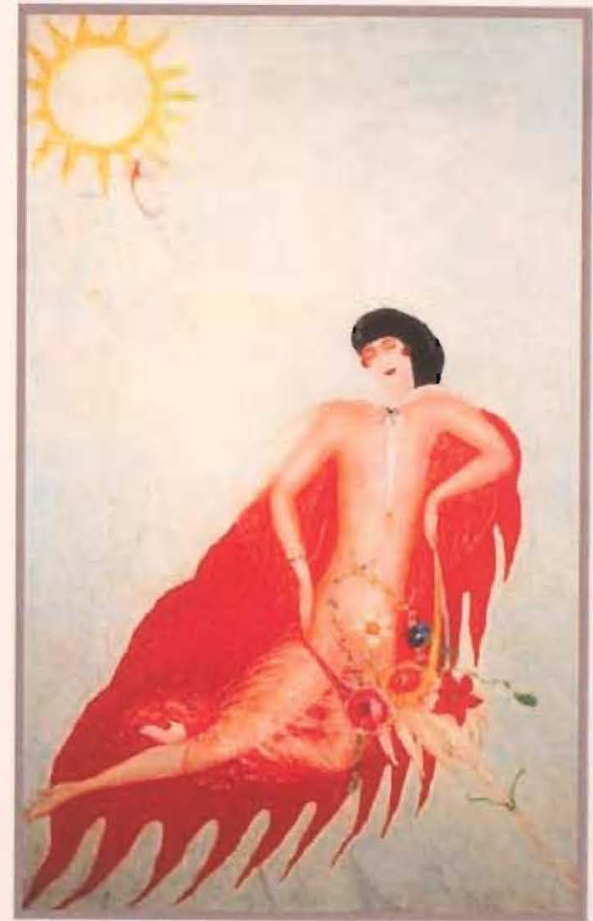

Fig. 7. Florine Stettheimer, Portrait of Myself (1923), $40 \times 26$ in. Columbia University, New York.

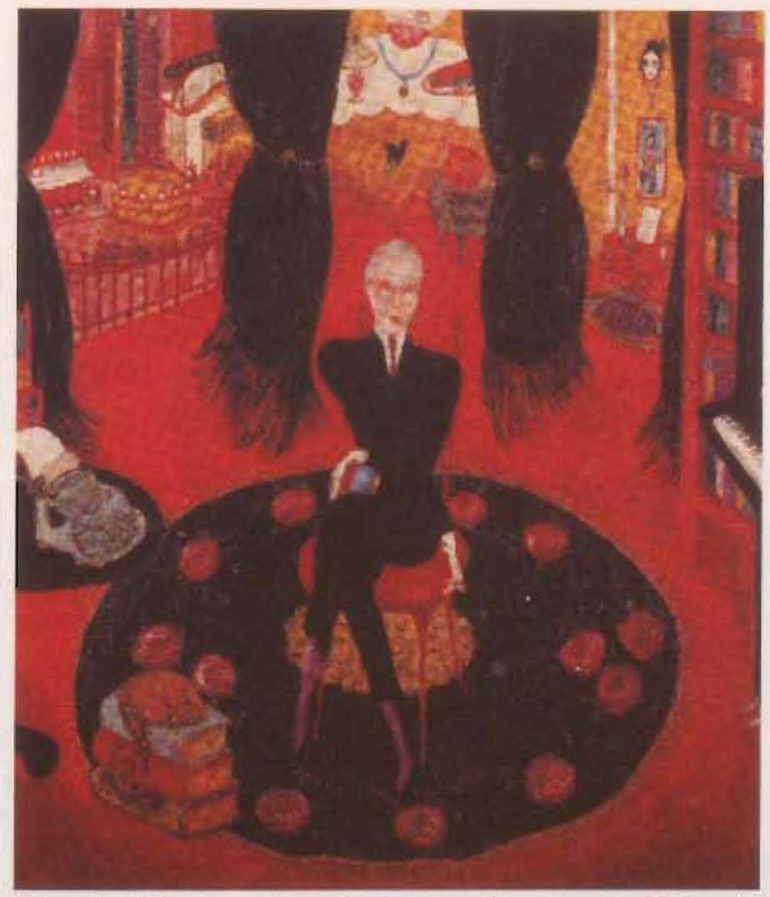

Fig. 8. Florine Stettheimer, Portrait of Carl Van Vechten (1922), $28 \times 26$ in. Yale Collection of American Literature, Beinecke Rare Book and Manuscript Library, Yale University, New Haven. 


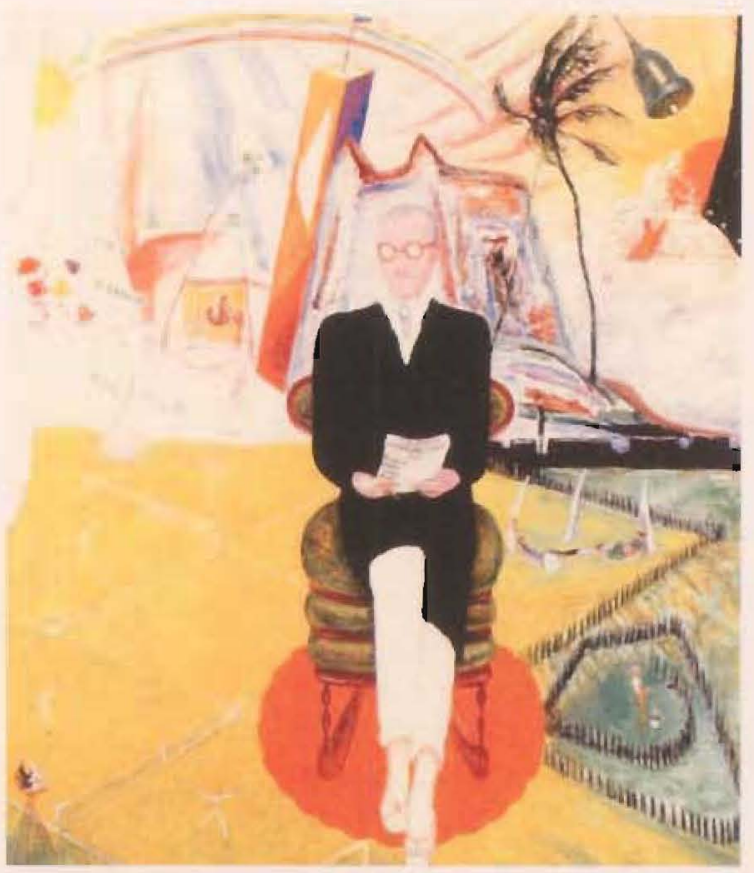

Fig. 9. Florine Stettheimer, Portrait of Henry McBride (1922), 36 × 30 in. Smith College Museum of Art, Northhampton. 